\title{
Measurement of Export Market Concentration for the Largest European Economic Integrations
}

\author{
Hrvoje Jošić, Berislav Žmuk, Ksenija Dumičić \\ University of Zagreb, Faculty of Economics and Business, Zagreb, Croatia
}

\section{Abstract}

Background: By joining different regional economic trade agreements, countries achieve preferential trade liberalisation. There are four main types of regional economic agreements in the world today: free trade area, customs union, common market, and economic and monetary union. Objectives: The goal of this paper is the measurement of the export market concentration for the largest European regional economic integrations in the period between 1995 and 2016. Methods/Approach: Various concentration measures have been used in the measurement of export market concentration, but the emphasis is placed on the standardized HerfindahlHirschman index as the basic measure of trade concentration. Results: Results of the analysis have shown that the highest concentration level of trade with countries worldwide is among the European Free Trade Association (EFTA) countries, whereas the EU-15 countries seem to have the lowest concentration level. On the other side, the Central European Free Trade Agreement (CEFTA) countries have the highest concentration level of trade with countries from the same group, and again the EU15 countries have the lowest concentration level, which indicates that the CEFTA countries implemented deeper integration processes related to mutual intra-regional trade. Conclusions: Deep integration processes led to lower values of export market concentration indices for intra-regional trade among countries of the same regional economic integration in comparison to trading with countries worldwide.

Keywords: European regional economic integrations; export market concentration; intra-regional trade; standardized concentration measures

JEL classification: C43, F15

Paper type: Research article

Received: Apr 25, 2018

Accepted: Jun 02, 2018

Citation: Jošić, H., Žmuk, B., Dumičić, K. (2019), "Measurement of Export Market Concentration for the Largest European Economic Integrations", Business Systems Research, Vol. 10, No. 2, pp. 61-72.

DOI: $10.2478 /$ bsrj-2019-018

\section{Introduction}

Throughout modern economic history, countries have been strengthening their trade with other countries by joining preferential trade agreements. In the aftermath of the Bretton Woods Conference and the Second World War, alongside the process of 
multilateral trade liberalisation, preferential trade liberalisation took place. By joining different regional economic trade agreements, countries have achieved preferential trade liberalisation (World Trade Organization, 2011). Although this process was in conflict with the Most Favoured Nation principle of the General Agreement on Tariffs and Trade, the creation of these preferential trade agreements was allowed if it encouraged international trade. Jacob Viner (1950) was the first to lay out the framework of the theory of economic integrations. He defined trade creation and trade diversion effects of the customs union. According to Balassa (1961), there are four main types of regional economic agreements in the world today: free trade area, customs union, common market, and economic and monetary union, herein listed from those with a shallow to those with a deeper degree of integration. The characteristics of the most advanced degree of integration are the elimination of barriers to free trade, the introduction of a common external tariff, the free movement of services, capital and labour, the harmonisation of economic policies and the introduction of the common currency.

Regional economic integrations can be especially important for small and landlocked countries since their influence their ability to diversify exports portfolio and to expand the number of markets that a country exports to (United Nations, 2011). This brings up the question of how regional economic integrations affect the global export market concentration. Export market concentration or export partner concentration is a degree to which a country relies on a limited number of partners as markets for its exports (United Nations, 2011 ). Salomon (2010) instead of export market concentration used term export diversification defined as a country's export product mix or export destination. Two main forms of export diversification are horizontal and vertical diversification. While horizontal diversification is related to the changes in the same sector (primary, secondary or tertiary) by diversifying country's export basket, vertical diversification entails a shift from the primary to the secondary or tertiary sector. Meilak (2008) related export concentration to the concentration of export goods and services destinations, implying a negative relationship with the country size variable and indicating higher export concentration in less developed countries (United Nations, 2011).

The goal of this paper is the measurement of export market concentration for the largest European regional economic integrations in the period between 1995 and 2016 using various concentration measures. The emphasis is placed on the standardized Herfindahl-Hirschman index as the basic measure of trade concentration. Other concentration measures used in the analysis are the concentration ratio, the Gini coefficient, the Rosenbluth index, and the Hall-Tideman index. The research hypothesis, which will be, tested states that deep integration processes led to lower values in export market concentration indices for European intra-regional trade between countries of the same regional economic integration in comparison to trading with countries worldwide in the observed period. Intra-regional trade refers to trade primarily between countries of the same region.

After the introduction, the first subheading comprises a literature review including theoretical and empirical aspects of export market concentration measurements for different countries and economic integrations. Methodology and data are presented in the methodology and data section while the next sections present results of the empirical analysis and discussion on the concentration analysis of the trade of European regional economic integrations. The final chapter presents concluding remarks. 


\section{Literature review}

Chauvin and Gaulier (2002) present and analyse three complementary approaches in order to address the potential of increasing intra-Southern African Development Community (SADC) trade: export diversification revealed comparative advantages and trade complementarity indices and indices based on the gravity model. Their static analysis suggests that further trade between SADC countries is limited due to concentrated and similar comparative advantages. In addition, they tend to have the same comparative disadvantages, especially in manufactured products. Pédussel Wu (2004) proposes a framework for measuring levels of regional integration using the database of regional integration, and he uses the ordered probit maximum likelihood estimation in a discrete choice. Characteristics of countries joining deeper regional economic integrations include a higher income, a democratic political system, a high number of inhabitants and landlockedness. Babatunde (2006) examined the impact of trade policy reform and regional integration on export performance in the Economic Community of West African States (ECOWAS) subregion. Using the gravity model, the results of the analysis have revealed that membership in preferential trade agreements within the ECOWAS sub-region is beneficial and trade-facilitating while the existence of artificial barriers to trade negatively affects export performance. Trade policy tools such as tariff and non-tariff barriers, credits to exchange rate policies and export subsidies should be used to reduce anti-export bias. On the other hand, other trade restrictive measures such as import prohibitions, quantitative restrictions and licensing, rules of origin and import duties and taxes should be reduced or eliminated.

Beine and Coulombe (2006) investigate the Canada-U.S. trade integration and its impact on the degree of export diversification of the Canadian regions. They compute specialization indices based on export data between Canada and the United States for 290 industries distinguishing between short and long run effects of economic integration on export diversification. The results indicate that trade integration between Canada and the United States positively affects export diversification in the long run, especially for the manufacturing sector. Bebczuk and Berrettoni (2006), based on data for 56 countries in the period from 1962 to 2002, unveiled a number of regularities regarding the determinants of export diversification: increased diversification in most countries, good macroeconomic performance stimulates export concentration, exporters of primary products tend to have more focused export structures than exporters of manufactures, etc. Huw Edwards (2006) applied the Lorenz curve and the Gini coefficient to the measurement of global and regional integration. Comparing nine economies, he found that the USA is the most globalised and India and China are the least globalised while smaller EU economies should be viewed as regionalised rather than globalised. He pointed out that further refinements are possible using a more sophisticated treatment of regionalism by making a multi-layer breakdown of regions. In particular, the United States is being treated as a unit in calculations so the results may be altered by splitting the country into sub-regions. Babones and Farabee-Siers (2010) explored export partner concentration for poor countries since the 1980s. They found that average export partner concentration among poor countries has barely changed since 1980 and has risen since the mid-1990s.

Ferdous (2011) investigates patterns and determinants of export diversification in East Asian economies. Export diversification has been almost steady over the years in East Asian economies, and the trade has been concentrated mainly in manufactured products. Greater economic integration in East Asian economies has led to export diversification while exchange rates and tariff rates have a significant negative 
impact on specialization. Carrère, Gourdon, and Olarreaga (2012) explore trade creation and trade diversion effects in the MENA region. They found evidence of an increase in intra-regional trade due to most preferential trade agreements and evidence of trade diversion in the Pan Arab Free Trade Agreement (PAFTA). There is a significant trade creation for resource poor countries, which benefit from the trade diversion of resource rich countries at the expenses of the rest of the world. In this way, PAFTA has helped to redistribute income from resource rich countries to resource poor countries. Zhelev and Tzanov (2012) evaluate Bulgaria's export competitiveness before and after the EU accession. They found that the EU accession has not accelerated structural transformation and processes of technological upgrading. There is also a low diversification of export performance, low factor intensity, technological sophistication, and lagging behind other Central and Eastern European (CEE) countries. The current export specialization level is not sustainable in the medium run, posing problems for long-term economic performance and catching up with other EU countries.

Pham (2014) assesses the impact of intra-regional trade on income inequality employing the gravity model for bilateral trade among 19 selected Asian-Pacific countries from 1998 to 2011 . An important finding of the paper is that the rise in intraregional exports can narrow within-country income inequality. This is a creation effect of intra-regional exports. The opposite is true for intra-regional imports. On the other side, developing countries can suffer negative effects of trading with developed countries or undesired diversion effects of trade. Almagro (2015) studies the relationship between trade agreements and the dynamics between political and economic factors surrounding the design of trade agreements. The results indicate that in comparison to democracies, autocracies sign fewer and fewer deep agreements. Deeper depth trade agreements have a significant effect on product export concentration in small states leading to more concentrated product exports. Another conclusion of this paper is that neither the volume nor the depth of trade has a significant effect on determining with whom countries trade or their market concentration.

According to Kaitibie, Al Jaidah, and Haq (2016), export market concentration and economic diversification are important risk mitigation strategies for a country that is heavily reliant on one sector for its economic growth. Neagu and Neagu (2016) track the economic evolution of specialisation and economic concentration in Romanian regions in the period from 2000 to 2013 using several statistical indices. According to the Hirschman-Herfindahl index, southern regions became more specialised. The Gini coefficient indicates different dynamics, i.e., the South-Eastern region is the only one specialised in the observed period. Both indices suggest a trend of diversification in all regions while the economic entropy increased in all regions. Paraschiv (2016) in the first of his three essays, evaluates the link between economic integration agreements and export diversity. Economic integration is not always associated with increased export diversity, and that depends on the type of economic integration. It also shows that the Eurozone formation had a negative effect on bilateral export diversification.

Chemingui and Eris (2017) revisit the empirical relationship between trade integration and business cycle synchronization using bilateral trade integration measures on a large sample of countries over the 1995-2013 period. Greater trade integration and bilateral trade intensity are positively associated with more synchronized business cycles when endogeneity issues are taken into account. An exception to the rule is the case of Arab countries where the relationship is the opposite, thus greater trade integration is associated with less synchronized business cycles. 


\section{Methodology}

In order to inspect export market concentration, three regional economic integrations, which include European countries, are observed. Accordingly, the analysis included countries that signed the Central European Free Trade Agreement (CEFTA), countries that are a part of the European Free Trade Association (EFTA) and countries, which are member states of the European Union as of 31 December 2003 (EU-15). In this paper, the export market concentration is observed in the period from 1995 to 2016. In the analysis, data from the United Nations Conference on Trade and Development (2017) database are used. Due to data availability limitations and changes in member countries of the regional economic integrations, data are not available for all countries from each of the observed regional economic integrations. Thus, countries included in the CEFTA integration are Albania, Bosnia and Herzegovina, Republic of Moldova and TFYR of Macedonia. Since 2008, the CEFTA integration has included Montenegro and Serbia. The EFTA integration includes Iceland, Norway, and Switzerland. Member states of the EU-15 are Austria, Belgium, Denmark, Finland, France, Germany, Greece, Ireland, Italy, Luxembourg, the Netherlands, Portugal, Spain, Sweden, and the United Kingdom.

The paper will investigate export concentrations levels of the observed European regional economic integrations. First, the concentration level of European regional economic integrations will be observed by taking into consideration trade with countries worldwide. After that, the concentration level of the trade with countries from the same group will be observed. The following standardized concentration measures are used in the analysis: the standardized concentration ratio, the standardized Gini coefficient, the standardized Herfindahl-Hirschman index, the standardized Rosenbluth index, and the standardized Hall-Tideman index. The standardization concentration measures are limited to the interval from 0 to 1 . On that way, conclusions that are more precise can be made about achieved concentration levels. The detailed definitions of used concentration measures can be found in Dumičić, Žmuk, and Knežević (2017). However, because the comparison of the concentration levels for trading with countries worldwide and with countries from the same group will be conducted by observing the standardized Herfindahl-Hirschman index, the equation for that measure is provided here.

The standardized Herfindahl-Hirschman index takes squared shares of units into account. If there were some units with large shares in compare to the share of other units, the standardized Herfindahl-Hirschman index would be closer to value 1. On that way, it will be pointed out that there is a high level of concentration. On the other side, if all units have relatively small shares, the sum of squared shares will be small and closer to value 0 . In that case, the conclusion would be that there is a low level of concentration. The standardized Herfindahl-Hirschman index is calculated as follows:

$$
H H I^{*}=\frac{\sum_{i=1}^{N} p_{i}^{2}-\frac{1}{N}}{1-\frac{1}{N}}
$$

where $H_{H}{ }^{*}$ is standardized Herfindahl-Hirschman index, $p_{i}$ is proportion or share of the i-th unit, $N$ is the total number of observed units or categories. 


\section{Results}

In this section, the trade concentration of European regional economic integrations is observed. First, the concentration level of the trade of regional economic integrations with countries worldwide is inspected, and after that, the concentration level of the trade of regional economic integrations with countries from the same group is observed. Afterwards, the concentration levels are compared by using the standardized Herfindahl-Hirschman concentration index.

Table 1 presents the values of selected standardized concentration measures in the CEFTA, the EFTA, and the EU-15 countries by observing their trade with other countries worldwide. The results suggest that the highest concentration level is among the EFTA countries, whereas the EU-15 countries seem to have the lowest concentration level of trade with countries worldwide. If the standardized Herfindahl-Hirschman concentration index is observed, it can be concluded that the CEFTA countries had a moderate concentration level of trade with countries worldwide in 2016, the EFTA countries had a high concentration level, whereas the EU-15 countries had a low concentration level in 2016.

Table 1

Selected Standardized Concentration Measures for the CEFTA, EFTA and the EU-15 Countries, Trade with Countries Worldwide, Selected Years (United Nations Conference on Trade and Development, 2017)

\begin{tabular}{|c|c|c|c|c|c|c|c|c|}
\hline \multirow{2}{*}{ Concentration measures } & \multicolumn{8}{|c|}{ Year } \\
\hline & 1995 & 1998 & 2001 & 2004 & 2007 & 2010 & 2013 & 2016 \\
\hline \multicolumn{9}{|l|}{ CEFTA countries* } \\
\hline Standardized conc. ratio 1 & 0.36 & 0.30 & 0.17 & 0.16 & 0.22 & 0.35 & 0.39 & 0.41 \\
\hline Standardized conc. ratio 2 & 0.80 & 0.61 & 0.62 & 0.59 & 0.68 & 0.62 & 0.62 & 0.63 \\
\hline Standardized conc. ratio 4 & 1.00 & 1.00 & 1.00 & 1.00 & 1.00 & 0.89 & 0.89 & 0.91 \\
\hline Standardized Gini coefficient & 0.54 & 0.41 & 0.33 & 0.30 & 0.38 & 0.54 & 0.55 & 0.58 \\
\hline Stan. Herfindahl-Hirschman index & 0.19 & 0.11 & 0.07 & 0.05 & 0.09 & 0.15 & 0.17 & 0.19 \\
\hline Stan. Rosenbluth index & 0.22 & 0.15 & 0.11 & 0.10 & 0.13 & 0.17 & 0.17 & 0.19 \\
\hline Stan. Hall-Tideman index & 0.33 & 0.45 & 0.54 & 0.57 & 0.49 & 0.31 & 0.31 & 0.28 \\
\hline \multicolumn{9}{|l|}{ EFTA countries** } \\
\hline Standardized conc. ratio 1 & 0.48 & 0.48 & 0.36 & 0.39 & 0.32 & 0.39 & 0.54 & 0.65 \\
\hline Standardized conc. ratio 2 & 0.98 & 0.98 & 0.98 & 0.98 & 0.98 & 0.98 & 0.99 & 0.98 \\
\hline Standardized Gini coefficient & 0.64 & 0.63 & 0.56 & 0.58 & 0.53 & 0.58 & 0.68 & 0.75 \\
\hline Stan. Herfindahl-Hirschman index & 0.31 & 0.30 & 0.25 & 0.26 & 0.24 & 0.26 & 0.35 & 0.45 \\
\hline Stan. Rosenbluth index & 0.37 & 0.37 & 0.30 & 0.31 & 0.28 & 0.31 & 0.42 & 0.51 \\
\hline Stan. Hall-Tideman index & 0.25 & 0.26 & 0.32 & 0.31 & 0.34 & 0.31 & 0.22 & 0.16 \\
\hline \multicolumn{9}{|l|}{ EU-15 countries*** } \\
\hline Standardized conc. ratio 1 & 0.20 & 0.19 & 0.20 & 0.21 & 0.23 & 0.23 & 0.22 & 0.24 \\
\hline Standardized conc. ratio 2 & 0.35 & 0.34 & 0.33 & 0.34 & 0.35 & 0.36 & 0.36 & 0.37 \\
\hline Standardized conc. ratio 4 & 0.59 & 0.59 & 0.58 & 0.56 & 0.58 & 0.59 & 0.58 & 0.59 \\
\hline Standardized conc. ratio 10 & 0.93 & 0.94 & 0.93 & 0.93 & 0.94 & 0.94 & 0.94 & 0.94 \\
\hline Standardized Gini coefficient & 0.54 & 0.54 & 0.53 & 0.53 & 0.54 & 0.55 & 0.55 & 0.55 \\
\hline Stan. Herfindahl-Hirschman index & 0.07 & 0.07 & 0.07 & 0.07 & 0.08 & 0.08 & 0.08 & 0.08 \\
\hline Stan. Rosenbluth index & 0.07 & 0.07 & 0.07 & 0.07 & 0.07 & 0.07 & 0.07 & 0.08 \\
\hline Stan. Hall-Tideman index & 0.30 & 0.31 & 0.31 & 0.31 & 0.31 & 0.30 & 0.30 & 0.29 \\
\hline
\end{tabular}

Source: Authors' work

Note: * In the period from 1995 to 2007 there were four countries in CEFTA. Since 2008 there have been six countries. ${ }^{* *}$ In the period from 1995 to 2016 there were three countries in EFTA. *** In the period from 1995 to 2016 , there were 15 countries in the EU-15. 
Table 2 shows the values of selected standardized concentration measures in the CEFTA, the EFTA, and the EU-15 countries by observing their trade with countries from the same group (intra-regional trade). According to the results, the CEFTA countries have the highest concentration level of trade with countries from the same group. Again, the EU-15 countries have the lowest concentration level. When the trade of regional economic integrations with countries from the same group is observed, the standardized Herfindahl-Hirschman concentration index shows that the CEFTA countries had a high concentration level in 2016 whereas the EFTA and the EU-15 countries had a low concentration level.

Table 2

Selected Standardized Concentration Measures for the CEFTA, EFTA and the EU-15 Countries, Trade with Countries from the same Group, Selected Years (United Nations Conference on Trade and Development, 2017)

\begin{tabular}{|c|c|c|c|c|c|c|c|c|}
\hline \multirow{2}{*}{ Concentration measures } & \multicolumn{8}{|c|}{ Year } \\
\hline & 1995 & 1998 & 2001 & 2004 & 2007 & 2010 & 2013 & 2016 \\
\hline \multicolumn{9}{|l|}{ CEFTA countries* } \\
\hline Standardized conc. ratio 1 & - & - & - & - & - & 0.46 & 0.50 & 0.55 \\
\hline Standardized conc. ratio 2 & - & - & - & - & - & 0.70 & 0.70 & 0.73 \\
\hline Standardized conc. ratio 4 & - & - & - & - & - & 0.97 & 0.94 & 0.96 \\
\hline Standardized Gini coefficient & & - & - & - & - & 0.68 & 0.67 & 0.71 \\
\hline Stan. Herfindahl-Hirschman index & - & - & - & - & - & 0.26 & 0.27 & 0.32 \\
\hline Stan. Rosenbluth index & - & - & - & - & - & 0.27 & 0.25 & 0.29 \\
\hline Stan. Hall-Tideman index & - & - & - & - & - & 0.20 & 0.21 & 0.18 \\
\hline \multicolumn{9}{|l|}{ EFTA countries** } \\
\hline Standardized conc. ratio 1 & 0.20 & 0.18 & 0.12 & 0.21 & 0.33 & 0.27 & 0.20 & 0.23 \\
\hline Standardized conc. ratio 2 & 0.84 & 0.75 & 0.72 & 0.82 & 0.83 & 0.80 & 0.83 & 0.81 \\
\hline Standardized Gini coefficient & 0.36 & 0.29 & 0.23 & 0.36 & 0.44 & 0.38 & 0.35 & 0.36 \\
\hline Stan. Herfindahl-Hirschman index & 0.12 & 0.07 & 0.05 & 0.11 & 0.15 & 0.11 & 0.11 & 0.10 \\
\hline Stan. Rosenbluth index & 0.16 & 0.12 & 0.09 & 0.16 & 0.21 & 0.17 & 0.15 & 0.16 \\
\hline Stan. Hall-Tideman index & 0.51 & 0.59 & 0.67 & 0.52 & 0.43 & 0.50 & 0.53 & 0.52 \\
\hline \multicolumn{9}{|l|}{ EU-15 countries*** } \\
\hline Standardized conc. ratio 1 & 0.18 & 0.16 & 0.17 & 0.19 & 0.20 & 0.19 & 0.18 & 0.19 \\
\hline Standardized conc. ratio 2 & 0.32 & 0.30 & 0.30 & 0.32 & 0.35 & 0.36 & 0.36 & 0.37 \\
\hline Standardized conc. ratio 4 & 0.55 & 0.54 & 0.56 & 0.57 & 0.59 & 0.60 & 0.61 & 0.60 \\
\hline Standardized conc. ratio 10 & 0.93 & 0.93 & 0.93 & 0.94 & 0.94 & 0.94 & 0.94 & 0.94 \\
\hline Standardized Gini coefficient & 0.52 & 0.50 & 0.51 & 0.53 & 0.54 & 0.55 & 0.55 & 0.55 \\
\hline Stan. Herfindahl-Hirschman index & 0.06 & 0.05 & 0.06 & 0.06 & 0.07 & 0.07 & 0.07 & 0.07 \\
\hline Stan. Rosenbluth index & 0.07 & 0.06 & 0.07 & 0.07 & 0.07 & 0.07 & 0.08 & 0.08 \\
\hline Stan. Hall-Tideman index & 0.33 & 0.34 & 0.33 & 0.32 & 0.31 & 0.30 & 0.30 & 0.30 \\
\hline
\end{tabular}

Source: Authors' work

Note: * In the period from 1995 to 2007 there were four countries in CEFTA. Since 2008 there have been six countries. Data are unavailable for the period before $2008 .{ }^{* *}$ In the period from 1995 to 2016 there were three countries in EFTA. ${ }^{* * *}$ In the period from 1995 to 2016, there were 15 countries in the EU-15.

In order to inspect whether integration processes led to lower values of export market concentration indices for intra-regional trade between countries of the same regional economic integration in comparison to trading with countries worldwide, the standardized Herfindahl-Hirschman concentration index values for CEFTA, EFTA, and the EU-15 are observed. The values of the standardized Herfindahl-Hirschman concentration index observing concentration levels for trading with countries 
worldwide and for trading within the group for the CEFTA countries are given in Figure 1, for the EFTA countries in Figure 2 and for the EU-15 countries in Figure 3.

According to Figure 1, the values of the standardized Herfindahl-Hirschman concentration index for the CEFTA countries are higher for trade within the group than for trade with countries worldwide. A limitation of the analysis is that the data for CEFTA trade within the group have been available only since 2008, i.e., after the accession of Montenegro and Serbia. On the other hand, results from Figure 2 indicate that concentration indices for intra-regional trade for the EFTA countries are lower than for trade with countries worldwide, thus supporting the hypothesis of the paper.

Figure 1

Standardized Herfindahl-Hirschman Concentration Index for the CEFTA Countries (United Nations Conference on Trade and Development, 2017)

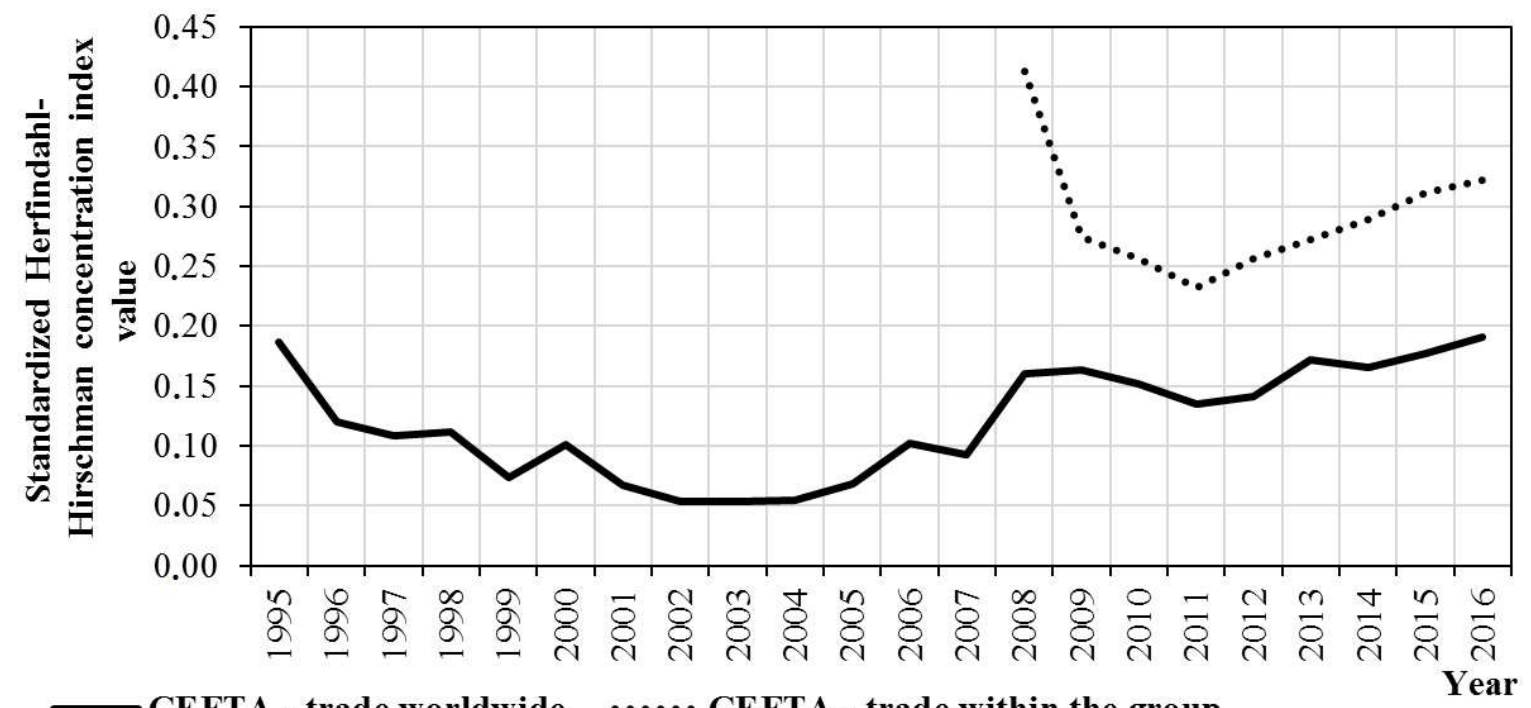

Source: Authors' illustration

Figure 2

Standardized Herfindahl-Hirschman Concentration Index for the EFTA Countries (United Nations Conference on Trade and Development, 2017)

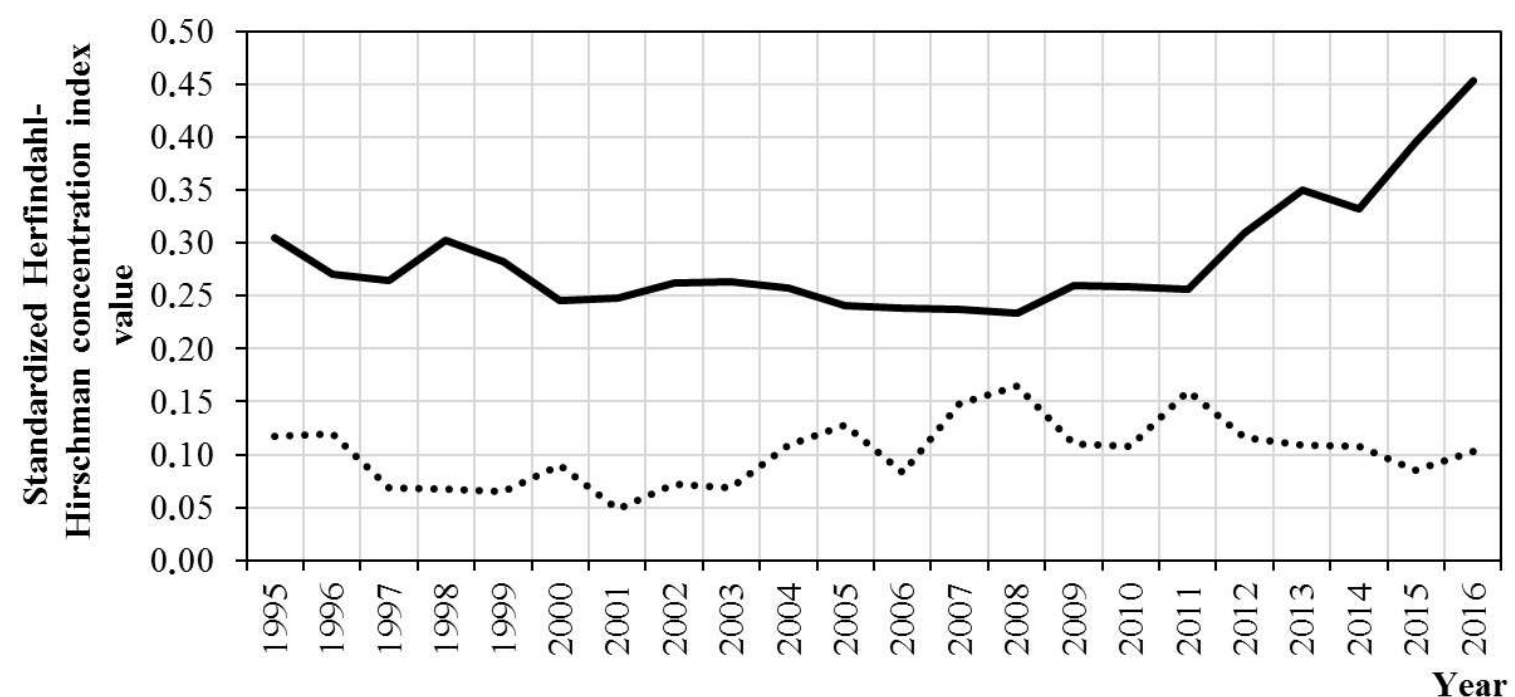

EFT A - trade worldwide

EFT A - trade within the group

Year

Source: Authors' illustration 
Similar behaviour is observed in Figure 3. Throughout the observed period, the values of concentration indices for the EU-15 intra-regional trade is lower than the values of concentration indices for the EU-15 trade with countries worldwide indicating deeper integration processes among the EU-15 countries. It can be concluded that the hypothesis of the paper cannot be fully accepted. Results of the analysis for the EFTA and the EU-15 countries support the hypothesis while the results of the concentration measurement for the CEFTA countries suggest the opposite, so further investigations in this field should be made.

Figure 3

Standardized Herfindahl-Hirschman Concentration Index for the EU-15 Countries (United Nations Conference on Trade and Development, 2017)

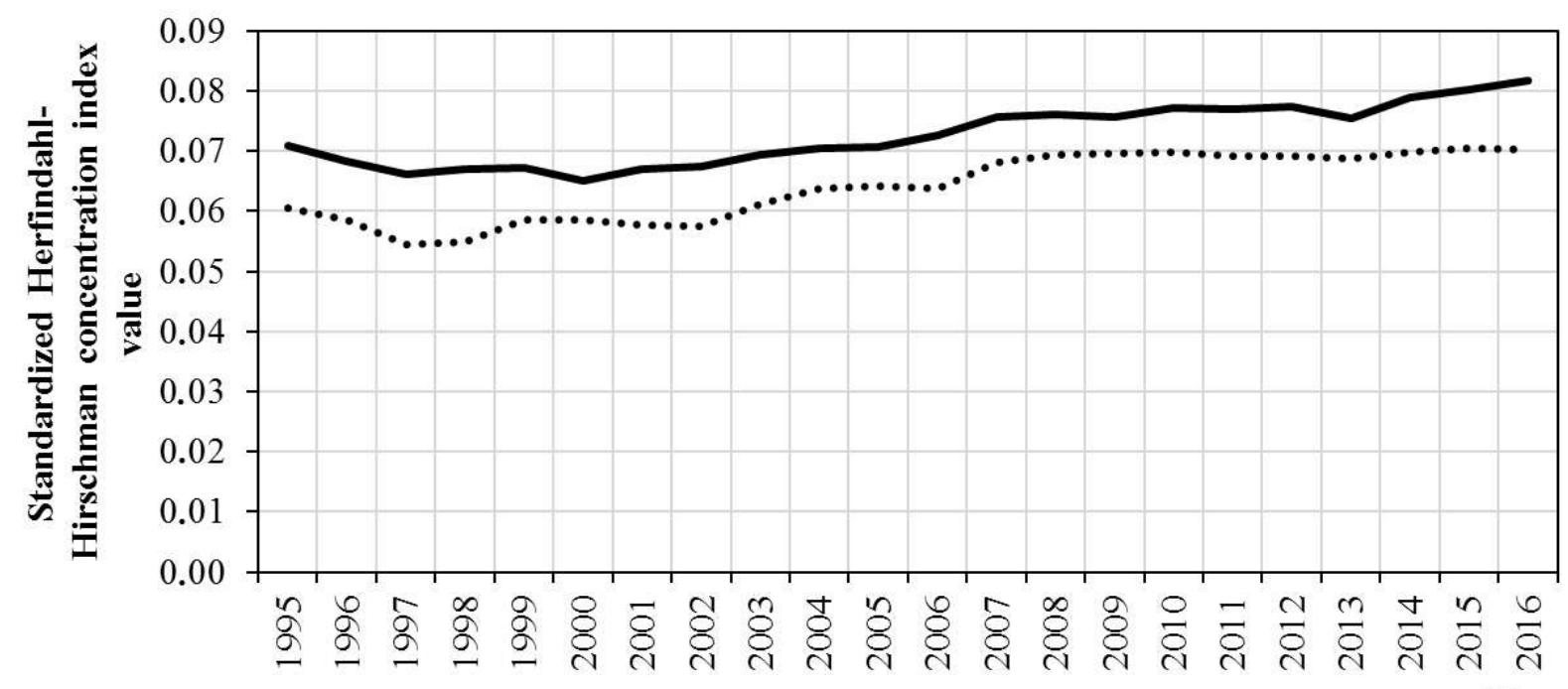

LU15 - trade worldwide

EU15 - trade within the group

Year

Source: Authors' illustration

In order to answer research question whether integration processes led to lower values of export market concentration indices for intra-regional trade between countries of the same regional economic integration in comparison to trading with countries worldwide, the values of standardized Herfindahl-Hirschman concentration indices for CEFTA, EFTA, and the EU-15 are compared for trade worldwide and within the group. Results for EFTA countries using Herfindahl-Hirschman and Rosenbluth index indicated the highest concentration level among the largest European economic integrations. CEFTA countries had a moderate concentration level of trade with countries worldwide while EU-15 countries had the lowest concentration level of trade with countries worldwide. When trade within a group of countries was observed, CEFTA countries had the highest concentration level of trade with countries from the same group. On the other side, the EU-15 countries again had the lowest concentration level. Comparison of trade with countries worldwide and within the group for the largest European economic integrations showed that concentration levels for EU-15 and CEFTA countries were lower for trade within the group in the observed period. It led to the support of research hypothesis that intra-regional trade between countries of the same regional economic integration is less concentrated, but that was not the case for CEFTA countries, which had more concentrated trade with countries of the same group. Limitation of the analysis for CEFTA countries was missing data for a period after the year 2008 (since the accession of Montenegro and Serbia) and a varying 
number of countries in the observed period because some countries left CEFTA before joining EU.

\section{Conclusion}

The aim of the paper was to investigate and measure export market concentration indices for the largest European regional economic integrations (namely the EU-15, EFTA and CEFTA) in the period between 1995 and 2016 using various concentration measures. The emphasis was placed on the standardized Herfindahl-Hirschman index as the basic measure of trade concentration, but other standardized concentration measures such as the standardized concentration ratio, the standardized Gini coefficient, the standardized Herfindahl-Hirschman index, the standardized Rosenbluth index, and the standardized Hall-Tideman index were used as well.

The hypothesis that was tested claimed "deep integration processes led to lower values of export market concentration indices for intra-regional trade between countries of the same regional economic integration in comparison to trading with countries worldwide". The results of the analysis indicate that the hypothesis of the paper cannot be fully accepted. Concentration indices for the EU-15 and EFTA intraregional trade are lower than the values of concentration indices for the EU-15 and EFTA trade with countries worldwide, but that was not the case for the CEFTA countries where the opposite was true. Limitations of the research are related to data missing periods (data for the CEFTA countries within group trade are available only after the year 2008, i.e., after the accession of Montenegro and Serbia) and a varying number of countries in CEFTA in the observed period. Recommendations for future research include the need to analyse export market concentration indices for the largest economic integrations in the world intended to promote intra-regional and global trade.

\section{References}

1. Almagro, A. S. (2015), "Trade Agreement Depth, Polity, and Export Concentration: A Political Economy Analysis of Trade Agreement Design", available at: https://as.nyu.edu/content/dam/nyu-as/politics/documents/Almagro_IRThesis.pdf (23 November 2017).

2. Babatunde, M. A. (2006), "Trade Policy Reform, Regional Integration and Export Performance in the ECOWAS Sub-Region", available at: https://www.gtap.agecon.purdue.edu/resources/download/2522.pdf (23 November 2017).

3. Babones, S., Farabee-Siers, R. M. (2010), "Global Export Partner Concentration since 1980: Trends in Dependency and Globalisation", in proceedings of the TASA 2010 Conference: Social Causes, Private Lives, The Australian Sociological Association, Hawthorn.

4. Balassa, B. (1961), The Theory of Economic Integration, Allew and Unwin, London.

5. Bebczuk, R. N., Berrettoni, N. D. (2006), "Explaining Export Diversification: An Empirical Analysis", CAF Research Program on Development Issues.

6. Beine, M., Coulombe, S. (2006), "Economic Integration and the Diversification of Regional Exports: Evidence from the Canadian-U.S. Free Trade Agreement", Journal of Economic Geography, Vol. 7, No. 1, pp. 93-111.

7. Carrère, C., Gourdon, J., Olarreaga, M. (2012), "Regional integration and natural resources: Who benefits? Evidence from MENA", International Economics, Vol. 131, pp. 23-41.

8. Chauvin, S., Gaulier, G. (2002), "Regional Trade Integration in Southern Africa", available at: http://www.cepii.fr/pdf_pub/wp/2002/wp2002-12.pdf (23 November 2017).

9. Chemingui, M., Eris, M. (2017) "Trade integration and business cycle synchronization: evidence from the experience of Arab countries", available at: http://erf.org.eg/wp-content/uploads/2017/03/Intl ERF23AC CheminguiMehmet.pdf 
(23 November 2017).

10. Dumičić, K., Žmuk, B., Knežević, B. (2017), "Concentration Level of the Largest World Retailers Based on Various Concentration Measures as Knowledge Needed by Decision Makers", in Lazibat, T., Wach, K., Knežević, B. (Eds.), Growth, Competitiveness and International Trade from the European Perspective, University of Zagreb, Faculty of Economics and Business, Zagreb, pp. 63-75.

11. Ferdous, F. B. (2011), "Pattern and Determinants of Export Diversification in East Asian Economies", available at: http://www.ipedr.com/vol5/nol/33-H00080.pdf (23 November 2017).

12. Huw Edwards, T. (2006), "Measuring global and regional trade integration in terms of concentration of access", available at: http://wrap.warwick.ac.uk/1900/1/WRAP Edwards wp20606.pdf (23 November 2017).

13. Kaitibie, S., Al Jaidah, M. I., Haq, M. M. (2016), "Export market concentration and the potential for export market diversification in the oil and gas sector in a small open economy", International Journal of Economic Perspectives, Vol. 10, No. 1, pp. 71-85.

14. Meilak, C. (2008), "Measuring export concentration: The implications for small states", Bank of Valletta Review, No. 37, pp. 35-48.

15. Neagu, O., Neagu, M. (2016), "Regional Specialisation and Economic Concentration in Romania", Studia Universitatis „Vasile Goldis” Arad - Economics Series, Vol. 26, No. 3, pp. 117.

16. Paraschiv, M. (2016), "Three essays on export concentration, international environmental agreements, and the carbon content of trade", available at:

http://uknowledge.uky.edu/economics_etds/25 (23 November 2017).

17. Pédussel Wu, J. (2004), "Measuring and Explaining Levels of Regional Economic Integration", ZEl working paper, No. B 12-2004, pp. 1-40.

18. Pham, T. H. H. (2014), "Intra-regional trade and income inequality: Where do we stand?", available at: https://ideas.repec.org/p/hal/wpaper/hal-01087366.html (23 November 2017).

19. Salomon, S. (2010), "A primer on export diversification: key concepts, theoretical underpinnings and empirical evidence", Growth and Crisis Unit World Bank Institute, pp. 123.

20. United Nations (2011), "Export dependence and export concentration", available at: http://www.undp.org/content/dam/undp/library/Poverty\%20Reduction/Inclusive\%20dev elopment/Towards\%20Human\%20Resilience/Towards_SustainingMDGProgress_Chapter 1. pdf (23 November 2017).

21. United Nations Conference on Trade and Development (2017), "Merchandise trade matrix - product groups, exports in thousands of dollars, annual, 1995-2016", available at: http://unctadstat.unctad.org/wds/TableViewer/tableView.aspx?Reportld=24739 (29 November 2017).

22. Viner, J. (1950), Customs Union Issue, Carnegie Endowment for International Peace, New York

23. World Trade Organization (2011), "World Trade Report 2011 - The WTO and preferential trade agreements: From co-existence to coherence", available at: https://www.wto.org/english/res_e/booksp_e/anrep_e/world_trade_reportl1_e.pdf (23 November 2017).

24. Zhelev, P., Tzanov, T. (2012), "Bulgaria's export competitiveness before and after EU accession", East-West Journal of Economics and Business, Vol. 15, No. 1-2, pp. 107-128. 


\section{About the authors}

Hrvoje Jošić, Assistant Professor, works at the International Economics Department in Faculty of Economics and Business in Zagreb since 2006. In 2011 he gained a doctoral degree at Faculty of Economics and Business, University of Zagreb. Currently, he is an Assistant Professor at the International Economics Faculty of Economics and Business, the University of Zagreb where he teaches International Economics course. His main research interests are theories of international trade, the balance of payment, and debt problem. He is an author of one book and many scientific papers in international journals and conferences. The author can be contacted at hjosic@efzg.hr.

Berislav Žmuk, Assistant Professor, graduated at the major Accounting, postgraduated Statistical Methods for Economic Analysis and Forecasting and gained his Ph.D. degree in Business Economics at Faculty of Economics and Business, University of Zagreb. Currently, he is an Assistant Professor at the Department of Statistics, Faculty of Economics and Business, the University of Zagreb where he teaches the following subjects: Statistics, Business Statistics, and Business Forecasting. His main research fields include applications of statistics in business and economy, survey methodology, and statistical quality control. The author can be contacted at bzmuk@efzg.hr.

Ksenija Dumičić is a Full Professor in Faculty of Economics and Business in Zagreb, University of Zagreb. Her main areas of teaching experience are sampling methods, statistics, business statistics, statistical methods of scientific research, statistical quality control and experimental design, methods and tools for quality management and quantitative methods. Her primary research field is sampling, statistics, business statistics, sampling for social and business surveys and sampling for opinion polling, while her secondary research field is statistical quality control, statistical methods for research; and business forecasting. She is author and co-author of 4 books and numerous contributions in scientific journals and conferences. The author can be contacted at kdumicic@efzg.hr. 